\title{
Determine of Copper Metal in Cooking Oil by Saponification Method with Atomic Absorption Spectrophotometer (AAS)
}

\author{
Usreg Sri Handajani, Muji Harsini and Zaldy Wicaksono
}

Departement of Chemistry, Faculty of Science and Technology, Airlangga University, Surabaya *Corresponding Author: usregsrihandajani@gmail.com

\section{Article history :}

Received

Revised

Accepted

Available online 20 August 2014

\section{GRAPHICAL ABSTRACT}

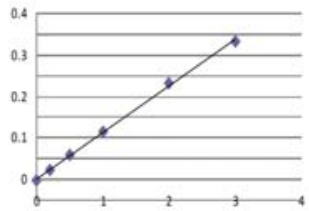

\section{ABSTRACT}

A research on the analysis of copper metal in the cooking oil saponification by AAS method. This study aimed to validate analytical methods, including precision and accuracy in the determination of copper metal in cooking oils through saponification and knowing destructed $\mathrm{Cu}$ content in cooking oils on the market. This research was done by creating a simulation of cooking oils and then added with a solution with various concentrations of $\mathrm{Cu}_{2+}$, reacted with $\mathrm{KOH}$ for saponification, then destructed dried, and absorbance was measured using an atomic absorption spectrometer. Results of accuracy (recovery) be obtained average of $96.88,97.35$, and $97.36 \%$ and precision values of $0.8233,0.3154$, and $0.4803 \%$. It can be concluded that this method is very well used to determine the concentration of copper metal contained in cooking oils, and $\mathrm{Cu}$ content in cooking oils on the market for bulk cooking oil 1 at $11.5 \mathrm{mg} / \mathrm{kg}$, bulk cooking oil 2 at $10.9 \mathrm{mg} / \mathrm{kg}$, and for branded cooking oil at $7.4 \mathrm{mg} / \mathrm{kg}$.

Keywords: cooking oil, saponification, $\mathrm{Cu}$, destruction

(c) 2014 Penerbit UTM Press. All rights reserved http://dx.doi.org/10.11113/mjfas.v10n4.270

\section{INTRODUCTION}

Cooking oil is one of the nine basic commodities in Indonesia. In 1993, public spending Indonesia for cooking oil consumption per capita per month is $4.5 \%$ of the total for food [1]. Consumption of cooking oil in Indonesia is expected to continue to increase in line with the increase in the number and income of the population.

In the cooking oil processing industry is possible oil contamination by metals derived from the means of production, especially the manufacture of cooking oil is done traditionally. With the continuous heating process during the production process, can cause the metal ions are released. One of the metals that are commonly used in the manufacture of production equipment is the metal copper $(\mathrm{Cu})$. Factors that played a role in the process of lipid peroxidation is the presence of transition metals such as $\mathrm{Fe}$ or $\mathrm{Cu}$ which is a powerful catalyst even in small quantities. Copper ions are in free form can bind back to the molecule or ion that has a lone pair of electrons to form a new complex ion. New complex ions formed can cause rancidity [7]. In this case the copper ions will form complexes with fatty acids that are in the cooking oil. Each type of food has a nutritional content and contamination are diverse. Metal contaminants typically act as heavy metals, which to some extent are present at very detrimental. Similarly, $\mathrm{Cu}$ contamination in the oil, there is a function as needed minerals and some are acting as contamination.

Metallic copper $(\mathrm{Cu})$ is one of the dangerous heavy metals. Copper metal can cause negative effects or toxic to humans at certain concentration limits. The symptoms that appear due to the toxicity of $\mathrm{Cu}$ metal on the weather man is halitosis, dry throat and stomach, feeling like vomiting and diarrhea continued for days, there is blood in the stool (faeces), dizziness and fever [5]. Toxicity owned by new copper will work and show the influence of metal when it has been entered into the body of the organism in large quantities or exceed the tolerance value related organisms [9]. Given the influence of $\mathrm{Cu}$ heavy metal toxicity, then $\mathrm{Cu}$ examination in cooking oil becomes very important.

A research on heavy metal content in clove oil have been carried out by using a wet destruction of acid $(\mathrm{HCl})$, after it was extracted [12]. The use of this method can actually be done, but this method requires a long time. This is because the destruction used wet-acid and concentrated strong acid ( $\mathrm{HCl}, \mathrm{HNO} 3$, and $\mathrm{H} 2 \mathrm{SO} 4)$ which is a polar compound. The compound will not be mixed with cooking oil that is non polar, so they are very difficult to react. Other problems also frequently occur in dry destruction, which will take several days of analysis. It is caused when used in temperatures that are too hot will cause burning cooking oil and endangering safety. It is therefore necessary to find a method that is safe, fast and gives good results. It is known that cooking oil saponifiable with the addition of a base, such as $\mathrm{NaOH}$ or $\mathrm{KOH}$. In this study will be carried out sample preparation cooking oil through the formation of soap that is not flammable. Dry so that destruction can be done safely. Principles of analysis of heavy metals in cooking oil by saponification method is to saponificated cooking oil by using a base to break down triglycerides into 
glycerol and soap (fatty acids). Soaps that have formed dry destructed in high temperature. The results of destruction dissolved in HNO3, then $\mathrm{Cu}$ (II) is checked by Atomic Absorption Spectrometry (AAS). This study aimed to validate analytical methods, including precision and accuracy in the determination of copper metal in cooking oil through saponification and knowing destructed $\mathrm{Cu}$ content in cooking oil on the market.

\section{EXPERIMENTAL}

\subsection{Materials and instruments}

The samples are simulated cooking oil and cooking oil in the market. Other materials used are kupro sulphate hydrate $\left(\mathrm{CuSO}_{4} .5 \mathrm{H}_{2} \mathrm{O}\right)$, nitric acid $\left(\mathrm{HNO}_{3}\right)$, hydrochloric acid $(\mathrm{HCl})$, potassium hydroxide $(\mathrm{KOH})$, sodium tetraborate $\left(\mathrm{Na}_{2} \mathrm{~B}_{4} \mathrm{O}_{7} .10 \mathrm{H}_{2} \mathrm{O}\right)$, methyl red (MM), phenolphthalein (PP), and filter paper.

The tools used in this study consisted of Atomic Absorption Spectrometry (AAS) Shimadzu AA 6200, milk strainer, analytical balance, furnace, burette, turning cooler, porcelain crucible, coconut milk container micrometer and tools that ordinary glass used in the laboratory.

\subsection{Preparation of standard curve}

Weigh $0.3929 \mathrm{~g} \mathrm{CuSO}_{4} .5 \mathrm{H}_{2} \mathrm{O}$ and diluted to $100 \mathrm{~mL}$ with distilled water to obtain stock solution. Prepare working solution by diluting stock solution. Prepare solution containing $0.2,0.5,1.0,2.0,3.0 \mathrm{ppm}$ by diluting $100 \mathrm{ppm}$ working solution to $100 \mathrm{~mL}$ with distilled water. Absorbance of 0.2, 0.5, 1.0, 2.0, 3.0 ppm standard measured by AAS. Wavelength used for analysis of copper is 324.7 $\mathrm{nm}$. The measurements obtained from linear curve expressing relation between absorbance of solution concentration, so that regression equations and correlation coefficients can be determined [10].

\subsection{Preparation of simulated cooking oils}

Weigh 400 g coconut meat peeled with smoothing steel, then shredded until smooth. Dissolve in water with 5:3 ratio. From 5 grated coconut added $3 \mathrm{~L}$ water. Grated coconut is squeezed to remove oil contained in granular coconut meat that has been refined. Coconut milk that formed was filtered using filter cloth to separate it with the waste. Coconut milk is allowed to stand until formed in two layers. Discarded water layer, and a layer of pure milk is heated to temperatures of approximately $120^{\circ} \mathrm{C}$ until there is an oil layer, then decanted and oil obtained. Simulated cooking oil obtained used in experiment 2.4., 2.5., and 2.6.

\subsection{Determination of saponification numbers}

Weigh $2 \mathrm{~g}$ simulated cooking oil, then slowly added $50 \mathrm{~mL} \mathrm{KOH} 0.7 \mathrm{M}$ and a few grains of stone boiling. Associated with cooling behind and carefully boiled for about half an hour, so oil and $\mathrm{KOH}$ mixed homogeneous and formed soap. Once cool, add a few drops of PP and excess $\mathrm{KOH}$ is titrated with $0.4772 \mathrm{~N} \mathrm{HCl}$ until it became colorless, then do the same thing against the blank (without using the sample titration). Replication is done 3 times.

\subsection{Addition of copper metal}

Weigh $1 \mathrm{~g}$ simulated cooking oil as much as four times, each of which is poured into the crucible. Crucible A filled without addition of $\mathrm{Cu}$ solution that serves as a control, crucible B filled with addition of $0.5 \mathrm{~mL}$ of $50 \mathrm{ppm}$ $\mathrm{Cu}$, crucible $\mathrm{C}$ filled with addition of $1 \mathrm{~mL}$ of $50 \mathrm{ppm} \mathrm{Cu}$, and crucible D filled with addition of $2 \mathrm{~mL}$ of $50 \mathrm{ppm} \mathrm{Cu}$. All mixed with rocking, while occasionally heated beaker glass. It is intended that $\mathrm{Cu}_{2}+$ metal can form complexes with fatty acids (approximately up not formed 2 layers). Replication is done 3 times.

\subsection{Saponification by dry destruction}

From results above (2.5.), each coupled with a rate of $5 \mathrm{~mL} \mathrm{KOH} \mathrm{1M}$ was heated on a hot plate. After the soap formed was transferred into the furnace crucible and heated at $500^{\circ} \mathrm{C}$ for $5 \mathrm{~h}$ to form gray and black authoring has been lost. Gained added ash 4N $\mathrm{HNO}_{3}$ to dissolve copper metal, put into $10 \mathrm{~mL}$ volumetric flask, and add distilled water up to the mark boundaries, concentration measured by AAS.

\subsection{Determination of copper metal}

Weigh $1 \mathrm{~g}$ sample of cooking oils on the market, which is bulk cooking oil and branded cooking oil, then saponifiable using $5 \mathrm{~mL} \mathrm{KOH} 1 \mathrm{M}$. After it, dried at a temperature of $500^{\circ} \mathrm{C}$ destructed for $\pm 5 \mathrm{~h}$. Ash obtained, then added $4 \mathrm{~N} \mathrm{HNO}_{3}$ to dissolve copper metal. Subsequently, the samples that have been prepared are put into $25 \mathrm{~mL}$ volumetric flask and add distilled water to mark boundaries. The absorbance measured by AAS.

\subsection{Analysis method validation}

\subsubsection{Precision}

Accuracy is a degree of repeatability of an analytical method. Stated accuracy results obtained with repeated measurements under the same conditions. Accuracy can be determined by calculating the standard deviation and coefficient of variation absorbance values of each standard solution with a concentration of equations (1) and (2):

$$
\begin{aligned}
& \mathrm{SD}=\sqrt{\frac{\sum\left(\mathrm{x}_{\mathrm{i}}-\overline{\mathrm{x}}\right)^{2}}{\mathrm{n}-1} \ldots .} \\
& \mathrm{KV}=\frac{\mathrm{SD}}{\mathrm{x}} \times 100 \% .
\end{aligned}
$$




\subsubsection{Determination of recovery}

Recovery can be determined by comparing analysis and actual $\mathrm{Cu}_{2}+$ concentration using saponification method. Recovery can be calculated by equation (3) below [13].

$$
\mathrm{R}=\frac{\mathrm{C}_{\mathrm{sp}}}{\mathrm{K}_{\mathrm{s}}} \times 100 \%
$$

\section{RESULTS \& DISCUSSION}

\subsection{Standard curve of $\mathrm{Cu}$}

Copper standard curve can be prepared by preparing standard solutions at different concentrations of $\mathrm{Cu}_{2+}$. The materials used to make a standard solution of $\mathrm{Cu}_{2+}$ is $\mathrm{CuSO}_{4} .5 \mathrm{H}_{2} \mathrm{O}$, because it is readily soluble in water and has a high purity. Preparation of $\mathrm{Cu}_{2}+$ standard with varying concentrations is due to the $\mathrm{Cu}$ concentration measured by AAS copper metal is linear in the range of concentrations. To determine $\mathrm{Cu}$ concentrations by AAS, use air-acetylene flame and measured at a wavelength of $342.7 \mathrm{~nm}$ [4]. Each standard solutions absorbance was measured by AAS, then made of the results obtained linear regression equation. The absorbance of samples showing ability to absorb electromagnetic radiation at maximum wavelength which is owned by a solution. Copper metal standard curve can be seen in Figure 1.

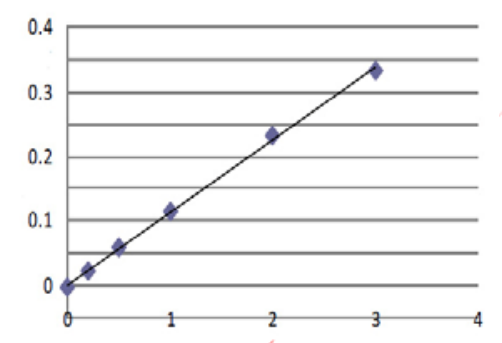

Fig. 1 Copper metal standard curve measured by AAS

The standard curve above shows that the greater $\mathrm{Cu} 2+$ concentration, the greater the absorbance. This is in accordance with Beer-Lambert law that the absorbance of a compound is proportional to the concentration [3]. By measuring the absorbance of the sample solution, plotted next to the standard curve, can be determined so that the metal concentrations in sample solution. Linear regression equation obtained was $\mathrm{y}=0.1127 \mathrm{x}+0.0005$ with a correlation coefficient of 0.9991 .

\subsection{Determination of Saponification Numbers}

Saponification numbers can be used to determine the amount of oil and fat molecules. Saponification numbers expressed as number (mg) of $\mathrm{KOH}$ needed to saponificated
$1 \mathrm{~g}$ of oil or fat. This saponification number determination can be used to determine the needs of $\mathrm{KOH}$ used for oil saponification. The analysis done by weighing $2 \mathrm{~g}$ of simulated cooking oil that added $50 \mathrm{~mL}$ of $0.7 \mathrm{M}$ alcoholic $\mathrm{KOH}$ and refluxed for 30 minutes. The excess of $\mathrm{KOH}$ is titrated with $0.5 \mathrm{~N} \mathrm{HCl}$ with phenolphthalein indicator added (PP). Thre result data can be seen in Table 1. It can be seen that average saponification number is $258.1346 \mathrm{mg} / \mathrm{g}$. Therefore, $1 \mathrm{M} \mathrm{KOH}$ used to saponificated $1 \mathrm{~g}$ oil needed by $5 \mathrm{~mL}$.

Table 1 The determination of saponification numbers

\begin{tabular}{|c|c|c|c|c|}
\hline No. & $\begin{array}{c}\text { Oil } \\
\text { Weight } \\
(\mathbf{g})\end{array}$ & $\begin{array}{c}\text { Vol. titration } \\
\text { to sample } \\
(\mathbf{m L})\end{array}$ & $\begin{array}{c}\text { Vol. titration } \\
\text { to blank } \\
(\mathbf{m L})\end{array}$ & $\begin{array}{c}\text { Saponification } \\
\text { number } \\
(\mathbf{m g} / \mathbf{g})\end{array}$ \\
\hline 1. & 2.0096 & 41.10 & 60.52 & 258.77 \\
\hline 2. & 2.0081 & 41.10 & 60.45 & 257.96 \\
\hline 3. & 2.0052 & 41.20 & 60.50 & 257.67 \\
\hline Average & 2.0076 & 41.13 & 60.49 & 258.13 \\
\hline
\end{tabular}

\subsection{Destruction of Cooking Oils}

Sample preparation is a very important step in analyzing the elements spectrometry. Saponification is a method by reacting oils (triglycerides) with a base to form a soap that aims to make sample not flammable when destructed. A metal content can be measured when the metals in the sample had been freed from organic material. The metal liberation of organic matter carried by the destruction. In the special section AAS instrument, the samples were prepared to experience the atomization [6]. Self destruction is one of the means used in sample preparation and aims to break down a compound into its elements so it can be analyzed further. Dry destruction is an overhaul by ashing sample and requires a certain heating temperature around $500^{\circ} \mathrm{C}$, but the temperature is highly dependent on the type of sample to be analyzed [8].

In the present study using method of dry destruction. Before the destruction of the saponification process is done in advance. The first thing to do is to prepare in advance of four pieces, each crucible crucible filled with oil up to $1 \mathrm{~g}$. A crucible filled with $1 \mathrm{~g}$ of oil without the addition of $\mathrm{Cu}$ aimed as a control. B crucible filled with $1 \mathrm{~g}$ of oil was added $0.5 \mathrm{~mL}$ of $50 \mathrm{ppm} \mathrm{Cu}, \mathrm{C}$ crucible filled with $1 \mathrm{~g}$ of oil was added $1 \mathrm{~mL}$ of $50 \mathrm{ppm} \mathrm{Cu}$, and D crucible filled with 1 $\mathrm{g}$ of oil was added $2 \mathrm{~mL}$ of $50 \mathrm{ppm} \mathrm{Cu}$. During the process of adding metal ions, the heating is done in order that the metal ions are added to and form a complex blend perfectly with oil. Here $\mathrm{Cu}$ have unpaired electrons that are highly reactive in catalyzing the oxidation and reduction reactions in the oil. Presence of transition metal ions such as $\mathrm{Cu}$ excess in the oil is potentially in the formation of ROS (reactive oxygen species), ROS is what will interact with $\mathrm{Cu}$ forming lipid peroxidation. In this case $\mathrm{Cu}$ forms a complex with fatty acids. $\mathrm{Cu}$ will be able to form complexes with fatty acid that has a number of atoms C14 to C20 [2], which can serve as a chelating agent. If a metal has dikhelat it will form a stable complex. Component fatty acids can function 
as a metal chelating agent because of the presence of one or two groups carboxyl adjacent hydroxyl groups react with metal ions to form a stable complex. Copper in the form of ions have oxidation number +1 and +2 , but it temodinamika stable as copper (II). Copper (II) with d9 structures have different stereochemistry, usually rectangular planar or distorted octahedral. Compounds used as CuSO4.5H2O can form complexes $\mathrm{Cu}$ rectangular shaped planar [13].

After that, each of the oil in the crucible reacted with alcoholic $\mathrm{KOH} 1 \mathrm{M}$ in $5 \mathrm{~mL} \mathrm{KOH}$ where the amount and concentration obtained from the determination of the saponification number. Used in this study due to alcohol alcoholic $\mathrm{KOH}$ to dissolve the oil phase and can also be mixed with the water phase. Once it is done again until the mixture is heating oil and soap with $\mathrm{KOH}$ to form perfectly. The process of destruction done to the soap that has been formed by means of authoring the furnace with a temperature of $500^{\circ} \mathrm{C}$ for approximately $5 \mathrm{~h}$. It aims to improve the process of destruction. Destruction is performed until the sample formed white ash and no residual carbon in the crucible. Ash formed was dissolved in $4 \mathrm{~N} \mathrm{HNO3}$, because the solubility properties of Cusoluble in nitric acid. Subsequently, the samples that have been prepared put into $10 \mathrm{~mL}$ volumetric flask and add distilled water to mark boundaries. In this method, the replication procedure is done three times to test the effectiveness of methods of lathering which is a new method in the analysis of metal content in cooking oil.

\subsection{Determination of copper metal in simulated cooking oils}

After destruction, absorbance of sample solutions and actual $\mathrm{Cu}$ concentration added in samples were measured. At the $\mathrm{Cu}$ measurement system uses flame. Atomization flame using air-acetylene fuel gas measured at a wavelength $342.7 \mathrm{~nm} \mathrm{Cu}$. Measurements were performed three times and the average value was taken for each sample solution. $\mathrm{Cu}$ concentration measurement results are added to the simulated cooking oil can be seen in Table 4.2.

Table 2 The actual Cu content added to the simulated oil

\begin{tabular}{|c|c|c|}
\hline $\begin{array}{c}\text { Initial Cu conc. addition } \\
(\mathbf{p p m})\end{array}$ & Cu conc. (ppm) & $\begin{array}{c}\text { Average Cu conc. } \\
\text { (ppm) }\end{array}$ \\
\hline $\mathrm{Cu} 50 \mathrm{ppm}$ & 48.705 & \multirow{2}{*}{48.728} \\
\hline $\mathrm{Cu} 50 \mathrm{ppm}$ & 48.764 & \\
\hline $\mathrm{Cu} 50 \mathrm{ppm}$ & 48.715 & \\
\hline
\end{tabular}

While the results of determination of $\mathrm{Cu}$ with various concentrations were added in the simulated cooking oil can be seen in Table 3. After determining the percent recovery was carried out by comparing the levels of $\mathrm{Cu}_{2}+$ obtained from the saponification method by measuring levels of $\mathrm{Cu}_{2}+$ solution of $50 \mathrm{ppm}$ (Table 2) prior to the saponification method (at first). Determination of percent recovery was conducted to determine how effective the method is performed in the analysis lathering metal in the oil. Expected percent recovery ranged from 95-105\% [13]. Initial assay results obtained from measurements of initial assay measurement results.

Table $3 \mathrm{Cu}$ metal concentration in simulated cooking oil

\begin{tabular}{|c|c|c|c|}
\hline $\begin{array}{c}\mathrm{Cu}^{2+} \text { addition } \\
(\mathrm{mg} / \mathrm{kg})\end{array}$ & $\begin{array}{c}\mathrm{Cu}^{2+} \text { conc. } \\
(\mathrm{mg} / \mathrm{kg})\end{array}$ & $\underset{(\mathrm{mg} / \mathbf{k g})}{\mathrm{Cu}^{2+} \text { conc. }}$ & $\begin{array}{l}\text { Recovery } \\
(\%)\end{array}$ \\
\hline \multirow{3}{*}{$\mathrm{Cu}^{2+} 25 \mathrm{ppm}$} & 23.427 & \multirow{3}{*}{24.364} & $96.15 \%$ \\
\hline & 23.811 & & $97.73 \%$ \\
\hline & 23.604 & & $96.75 \%$ \\
\hline \multirow{3}{*}{$\mathrm{Cu}^{2+} 50 \mathrm{ppm}$} & 47.541 & \multirow{3}{*}{48.728} & $97.56 \%$ \\
\hline & 47.288 & & $97.04 \%$ \\
\hline & 47.329 & & $97.13 \%$ \\
\hline \multirow{3}{*}{$\mathrm{Cu}^{2+} 100 \mathrm{ppm}$} & 94.828 & \multirow{3}{*}{97.456} & $97.30 \%$ \\
\hline & 94.452 & & $96.92 \%$ \\
\hline & 95.362 & & $97.85 \%$ \\
\hline
\end{tabular}

The results of accuracy (recovery) of the above table shows that the first, second, and third simulations oil with addition of various $\mathrm{Cu}$ concentrations obtained good results as entered in the expected range (95-105\%).

In the first treatment with the addition of $25 \mathrm{ppm} \mathrm{Cu}$ results accuracy (recovery) of 96.15, 97.73, and 96.75\%. It is also found in the second and third treatment with the addition of 50 and $100 \mathrm{ppm} \mathrm{Cu}$ gives results accuracy (recovery) of 97.56, 97.04, 97.13, 97.30, 96.92, and 97.85\% respectively, these values into the expected range, while to measure the accuracy of the saponification method we use analytical accuracy (precision).

Accuracy is the result obtained with the same measurements on the way over and under the same conditions. And the value obtained for the addition of 25 ppm Cu KV $=0.8233 \%$, for the addition of $50 \mathrm{ppm} \mathrm{Cu} \mathrm{KV}$ $=0.3154 \%$ and the addition of $100 \mathrm{ppm} \mathrm{Cu} \mathrm{KV}=0.4803 \%$ accuracy where the limits should not be more than 3\%. By looking at the values of accuracy and precision in the above, we can conclude this method is best used to analyze heavy metals in cooking oils.

\subsection{ANOVA Test}

One-way analysis of variance classification used in the experiment by using a single factor. ANOVA was used to compare three or more things "the state" as well. Analysis of variance procedure was introduced by R.A. Fisher, trying to analyze the diversity of the responses and divide into sections dealing with the diversity of known sources and the remainder attributed to random error (random error). Known source of variation is associated with the independent variables, namely the factors tested. In this case compare whether there were significant differences between the additions of $\mathrm{Cu}$ with varying levels of $\mathrm{Cu}$ initially used 
to test the F-test, using the table F. Anova test shown in Table 4.

Tabel 4 Determination of ANOVA Test

\begin{tabular}{|c|c|c|c|c|c|}
\hline Replication & A & B & C & D & \\
\hline 1 & 96.15 & 97.56 & 97.30 & 97.41 & \multirow{3}{*}{ TOTAL } \\
\hline 2 & 97.73 & 97.73 & 96.92 & 97.53 & \\
\hline 3 & 96.75 & 96.75 & 97.85 & 97.43 & \\
\hline $\begin{array}{l}\text { Total } \\
\text { results }\end{array}$ & 290.63 & 292.04 & 292.08 & 292.37 & 1167.12 \\
\hline Replication & 3 & 3 & 3 & 3 & 12 \\
\hline $\begin{array}{l}\text { Average } \\
\text { results }\end{array}$ & 96.88 & 97.35 & 97.36 & 97.46 & \\
\hline$\left(\sum x\right)^{2}$ & 28156.538 & 28429.669 & 28437.345 & 28493.414 & 113516.966 \\
\hline$\frac{\left(\sum x\right)^{2}}{n}$ & 28155.266 & 28429.121 & 28436.909 & 28493.406 & 113514.702 \\
\hline $\begin{array}{l}\text { Note: } \\
A=\% \text { reco } \\
B=\% \text { reco } \\
C=\% \text { reco } \\
D=\% \text { reco }\end{array}$ & $\begin{array}{l}\text { of } \mathrm{Cu} \\
\text { of } \mathrm{Cu} \\
\text { actua }\end{array}$ & $\mathrm{m}$ add & & & \\
\hline
\end{tabular}

From the calculation can be seen that the F-count value 0.717 , while the $\mathrm{F}$ table value $=4.07$. We can conclude that there is no difference between the treatment effect. Means lathering using this variation does not affect the concentration of the final product concentration.

\subsection{Determination of copper metal in cooking oil on the market}

In the determination of $\mathrm{Cu}$ metal in oil used 3 samples, respectively, are 2 kinds of bulk cooking oil and 1 kind of branded cooking oil. The sample of bulk cooking oil on the market is a palm cooking oil, while the simulated cooking oil using coconut cooking oil. It can be allowed due to palm and coconut cooking oil are the main content of triglycerides and saponifiable. Analysis of this cooking oil sample is the same as the simulated cooking oil processing, the samples were diluted in $25 \mathrm{~mL}$ volumetric flask and replicate measurements performed three times.

Table 5 Determination of $\mathrm{Cu}$ in cooking oils in the market

\begin{tabular}{|c|c|c|c|}
\hline Sample & Absorbance & Conc. (ppm) & Conc. (mg/kg) \\
\hline Bulk cooking oil 1 & 0.0723 & 0.4593 & 11.5 \\
\hline Bulk cooking oil 2 & 0.0687 & 0.4367 & 10.9 \\
\hline Branded cooking oil & 0.0469 & 0.2979 & 7.4 \\
\hline
\end{tabular}

It can be seen that $\mathrm{Cu}$ metal content in bulk cooking oil is greater than in branded cooking oil. This is because there are possible additional processes contaminated by metals in bulk cooking oil. Given the quality requirements of $\mathrm{Cu}$ metal content in the oil is determined by the Indonesian national standard [11] is equal to $0.1 \mathrm{mg} / \mathrm{kg}, \mathrm{Cu}$ content in the measured samples of cooking oil exceeds the allowed threshold making it less suitable for consumption.

\section{CONCLUSION}

The research methods of $\mathrm{Cu}$ metal content in cooking oils through saponification gives good results. In the first treatment, with addition of $25 \mathrm{ppm} \mathrm{Cu}$ results accuracy (recovery) average of $96.88 \%$ with precision values of $0.7922 \%$. In the second treatment, with addition of $50 \mathrm{ppm}$ $\mathrm{Cu}$ results accuracy (recovery) average of $97.35 \%$ with precision values of $0.2575 \%$, and with addition of $100 \mathrm{ppm}$ $\mathrm{Cu}$ results accuracy (recovery) of $97.36 \%$ with precision values of $0.3162 \%$. The F-test result showed no difference between the various treatments.

The copper metal content in cooking oils in the market for bulk cooking oil 1 had higher concentration at $1.04 \mathrm{mg} / 100 \mathrm{~g}$, bulk cooking oil 2 at $1.9 \mathrm{mg} / 100 \mathrm{~g}$, and branded cooking oil at $0.74 \mathrm{mg} / 100 \mathrm{~g}$, this shows that bulk cooking oil has higher Cú content than branded cooking oil.

\section{ACKNOWLEDGEMENT}

The authors thank to Department of Chemistry, Faculty of Science and Technology, Airlangga University, Surabaya for facilities.

\section{REFERENCES}

[1] Anonim. Statistik Indonesia, Biro Pusat Statistik, Jakarta, 1994

[2] Bargemann, D., Smolders, C.A. Liquid Membranes, Synthesis Membranes Science, Engineering and Applications, D. Reidel publishing Company, 1986, 567-579.

[3] Cantle, J.E. Techniques and Instrumentation in Analytical Chemistry, Atomic Absorption Spectrometry, Volume 5, Elsevier Scientific Publishing Co., Amsterdam, 1982.

[4] Christian, D., Gary. Analytical Chemistry, John Wiley and Sons Inc., New York, 1994.

[5] Darmono. Logam dan Sistem Biologi Makhluk Hidup, Universitas Indonesia Press, Jakarta, 1995.

[6] Greenberg, A.E., Lenore,S.C., Andrew, D.E. Metals by Electro Thermal Atomic Absorption Spectrometry in Standard Methods for Examination of Water and Water Waste, 18th Edition, American Public Health Association, Washington, 1992.

[7] Kuslan. Aditif Makanan, Majalah Departemen Kesehatan RI No.15 Tahun IV, 1985.

[8] Noerdin, D. Hidrogen Peroksida sebagai Pengoksida Basah pada Analisa Renik Bahan Organik, Departemen Kimia ITB, Bandung, 1982.

[9] Palar, H. Pencemaran dan Toksikologi Logam Berat, Rineka Cipta, Jakarta, 1994.

[10] Robinson, Trevor. Kandungan Organik Tumbuhan Tinggi,Penerbit ITB, Bandung, 1991.

[11] SNI, 01-3741-2002, Syarat Mutu Minyak Goreng, Badan Standardisasi Nasional.Jakarta.

[12] Sujalmi. Penentuan Renik Logam Berat dalam Minyak DaunCengkeh Hasil Industri Rakyat, Departemen Kimia ITB, Bandung, 1985.

[13] Sukardjo. Kimia Koordinasi, Bumi Aksara, Jakarta, 1985. 